\title{
Installation of Carbon Monoxide Detectors
}

\author{
RADOJE B. JEVTIĆ, School for Electrical Engineering „, Nikola Tesla“, Niš \\ MILAN D. BLAGOJEVIĆ, University of Niš, \\ Original scientific paper \\ UDC: 614.842 .4 \\ Faculty of Occupational Safety, Niš \\ DOI: $10.5937 /$ tehnika1901152J
}

\begin{abstract}
One of the most important tasks in fire protection is the arrangement of fire detectors in object. Fire detectors can be divided on different ways, depending on different factors. Their selection, arrangement, number and location depend from many different factors. One of the most complicated and the most demanded fire detectors in the sense of realisation and sensibility is the carbon monoxide detector. This paper was written to present the arrangement of carbon monoxide detectors, their realisation and main rules for locating, related to some valid standards.
\end{abstract}

Key words: detector, arrangement, $\mathrm{CO}$, standard

\section{INTRODUCTION}

The selection of appropriate fire detector in fire protection systems design is conditioned by many different factors, such as expected development of fire at early stage, dimensions and geometry in object (rooms surface and height), ambient parameters (temperature, humidity, air flow speed and others) and different obstruction parameters.

As an example, standard EN 54-14 in the 6.4 part (6.4 Selection of detectors and manual call point) notes that fire selection of appropriate fire detector should be considered according to next factors: materials that protected object were made of, space configuration, ventilation and heat effects, ambient conditions, false alarms possibilities and law regulative.

Of course, there is no universal fire detector for every possible appliance. The selection of fire detectors also depends of dominate combustion product during fire. Combustion products present the base for fire detection, no matter on fire development speed. According to many literatures, smoke detectors present $90 \%$ of all installed fire detectors.

The most important general factor for effective fire detection is the complete response time of the fire detector, regardless to which fire detector will be applied. This factor directly influences on the complete respon-

Author's address: Radoje Jevtić, School for Electrical Engineering „Nikola Tesla“, Niš, Aleksandra Medvedeva 18

e-mail: milan.jvtc@gmail.com

Paper received: 16.01.2019.

Paper accepted: 23.01.2019. se time of detection system. The complete response time depends on several times intervals: concrete danger detection time, fire products transfer time, time of fire rising, fire detector`s response time and effective response time. It is important to note that almost all modern fire detectors can be easily installed and reinstalled, and, during the system`s operation time, they can be reset unlimited numbers of times, directly at the detector's location or by remote from the central unit. One of the most important fire detectors, according to its realisation and way of functioning is the carbon monoxide detector $[1,2]$.

\section{CARBON MONOXIDE- CHARACTERISTICS}

Carbon monoxide presents one of the most dangers combustion products that can cause fatal consequences on human lives. Electronic formula of carbon monoxide can be presented by two formulas. According to the first formula, carbon and oxygen atoms were connected by double connection; according to the second formula, molecule of carbon monoxide comprehends also and donor-acceptor connection where oxygen presents donor and carbon presents acceptor.

Generally, carbon monoxide presents gas without color, smell and taste. It is easier than air $(0,97)$ what enables it to impend. It arises during incomplete combustion of materials that comprehend carbon. In the mixture with air, it can burn with a blue flame and creates carbon dioxide. Mixture of carbon monoxide and air is very often highly explosive- only the spark is enough to make an explosion. The explosion fields of gases and vapors in the air presented in \% of volume are presented on figure 1 (marked with red color). 


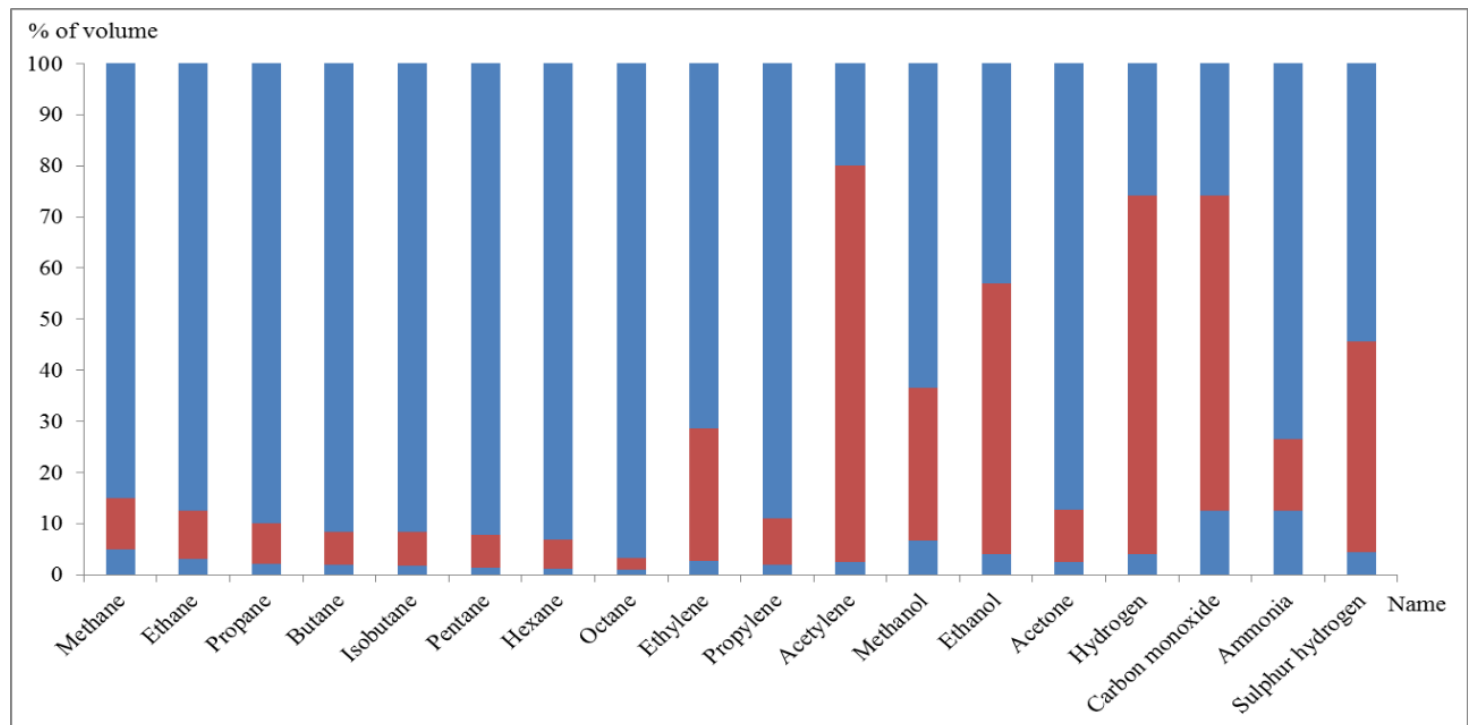

Figure 1 - Explosive bounds of gases and vapors in the air and explosion fields presented in \% of volume

The explosion field of carbon monoxide mixture with air is very wide (from $12.5 \%$ to $74.2 \%$ ), according to figure 1 .It is an easy to conclude that carbon monoxide has very wide explosive field and that big probability for its explosion almost always exists.

In the laboratory conditions, carbon monoxide can be gained in the chemical reaction where the water was deducted from ant's acid, according to the reaction (1):

$\mathrm{HCOOH}=\mathrm{H}_{2} \mathrm{O}+\mathrm{CO}$.

Practically, this reaction is realized by effect of concentrate $\mathrm{H}_{2} \mathrm{SO}_{4}$ on liquid $\mathrm{HCOOH}$. The second way is warming of oxalate acid or potassium ferro cyanide also with concentrate $\mathrm{H}_{2} \mathrm{SO}_{4}$, what is presented with reaction (2) and (3).

$$
\begin{aligned}
& \mathrm{H}_{2} \mathrm{C}_{2} \mathrm{O}_{4}=\mathrm{CO}+\mathrm{CO}_{2}+\mathrm{H}_{2} \mathrm{O} \\
& \mathrm{K}_{4}\left[\mathrm{Fe}(\mathrm{CN})_{6}\right]+6 \mathrm{H}_{2} \mathrm{SO}_{4}+6 \mathrm{H}_{2} \mathrm{O}=2 \mathrm{~K}_{2} \mathrm{SO}_{4}+ \\
& +\mathrm{FeSO}_{4}+3\left(\mathrm{NH}_{4}\right)_{2} \mathrm{SO}_{4}+6 \mathrm{CO}
\end{aligned}
$$

The exposition sources of carbon monoxide can be different: in the ironworks; in the foundries; in the coil mines; in the gas stations; during oil, wood and coil distillations; during welding; during production of paper, formaldehyde and carbides; in the forges; in the kitchens; in the car's exhaust gases etc. [3-5].

Carbon monoxide penetrates in human organism by inhalation. It diffuses through alveolocapillary membranes and it connects with haemoglobin in erythrocytes, at the same place where in the normal conditions oxygen connects with haemoglobin and creates carboxyhaemoglobin. Carboxyhaemoglobin presents stabile complex of carbon monoxide and haemoglobin and it is not in condition to accept or give oxygen so it implies with reduction of oxygen for tissues. The part of carbon monoxide that remains in plasma diffuses into tissues, particularly in the muscle and nerve tissues, where it connects for enzymes that has hem group (Cytochrome a3, P 540) wherewith disrupts cellular breathing. The biggest part of carbon monoxide is eliminated unchanged by expired air until smaller part oxides into carbon dioxide. The damages that can be inflicted are huge; it harms hart, muscles, central nerve system, lungs, kidneys, eyes, sense for hearing and balance and causes different metabolic destructions [6].

There are many carbon monoxide exposure limits set by different organisation, such as: NIOSH, ACGIH, ASHRAE and others. The carbon monoxide concentration level is usually measured in the way called ppm-parts per million. That means, for example, that 1000 ppm CO has 1000 molecules of carbon monoxide for every 999000 molecules of air what is equal to 0.1 $\%$ of gas volume. According to mass, $1 \mathrm{ppm}$ relates to $1 \mathrm{mg}$ in $1 \mathrm{~kg}$. Health effects and other information related to carbon monoxide level and its influence on humans are presented in table 1 [7].

Table 1. Health effects and other needed information related to carbon monoxide level (table source: https://www.detectcarbonmonoxide. com/co-health-risks/)

\begin{tabular}{|l|l|}
\hline $\begin{array}{l}\text { CO level } \\
(\mathrm{ppm})\end{array}$ & Health Effects and other information \\
\hline 0 & Normal, fresh air. \\
\hline 9 & $\begin{array}{l}\text { Maximum recommended indoor CO } \\
\text { level (ASHRAE). }\end{array}$ \\
\hline $10-24$ & $\begin{array}{l}\text { Possible health effects with long-term } \\
\text { exposure. }\end{array}$ \\
\hline 25 & $\begin{array}{l}\text { Max TWA Exposure for 8 hour work-day } \\
\text { (ACGIH). } \\
\text { Pocket CO TWA warning sounds each hour. }\end{array}$ \\
\hline
\end{tabular}




\begin{tabular}{|c|c|}
\hline $\begin{array}{l}\text { CO level } \\
(\mathrm{ppm})\end{array}$ & Health Effects and other information \\
\hline 50 & $\begin{array}{l}\text { Maximum permissible exposure in workplace } \\
\text { (OSHA). } \\
\text { First Pocket CO ALARM starts (optional, } \\
\text { every } 20 \text { seconds). }\end{array}$ \\
\hline 100 & Slight headache after 1-2 hours. \\
\hline 125 & $\begin{array}{l}\text { Second Pocket CO ALARM starts (every } 10 \\
\text { seconds). }\end{array}$ \\
\hline 200 & $\begin{array}{l}\text { Dizziness, nausea, fatigue, headache after 2-3 } \\
\text { hours of exposure. }\end{array}$ \\
\hline 400 & $\begin{array}{l}\text { Headache and nausea after } 1-2 \text { hours of } \\
\text { exposure. } \\
\text { Life threatening in } 3 \text { hours. } \\
\text { Third Pocket CO ALARM starts (every } 5 \\
\text { seconds). }\end{array}$ \\
\hline 800 & $\begin{array}{l}\text { Headache, nausea, and dizziness after } 45 \\
\text { minutes; collapse and unconsciousness after } 1 \\
\text { hour of exposure. } \\
\text { Death within } 2-3 \text { hours. }\end{array}$ \\
\hline 1000 & Loss of consciousness after 1 hour of exposure. \\
\hline 1600 & $\begin{array}{l}\text { Headache, nausea, and dizziness after } 20 \\
\text { minutes of exposure. } \\
\text { Death within } 1-2 \text { hours. }\end{array}$ \\
\hline 3200 & $\begin{array}{l}\text { Headache, nausea, and dizziness after } 5-10 \\
\text { minutes; collapse and unconsciousness after } 30 \\
\text { minutes of exposure. } \\
\text { Death within } 1 \text { hour. }\end{array}$ \\
\hline 6400 & Death within 30 minutes. \\
\hline 12800 & $\begin{array}{l}\text { Immediate physiological effects, } \\
\text { unconsciousness. } \\
\text { Death within 1-3 minutes of exposure. }\end{array}$ \\
\hline
\end{tabular}

\section{THE PRINCIPLE OF CARBON MONOXIDE DETECTOR REALISATION}

Modern carbon monoxide detectors can be realised as semiconductor detectors, electrochemical detectors, bio-imaging detectors and optical-chemistry detectors of carbon monoxide.

The principle of semiconductor carbon monoxide detector`s functioning lies in appliance of some semiconductor material such as, in the most of cases, stannic oxide $-\mathrm{SnO}_{2}$. This material is heated at $400{ }^{\circ} \mathrm{C}$ by electrical stimulus. The electrical resistance of this way formed semiconductor element was inversely proportional to carbon monoxide concentration in the detector`s chamber. By measuring of initial current, the correct information about carbon monoxide concentration can be gotten. This type of carbon monoxide sensors have lifetime from 3 to 5 years because of material consuming. One of such sensors types, MQ$7 \mathrm{~B}$ is presented on figure 2 . For example, it works at normal ambient conditions (temperature at $22{ }^{\circ} \mathrm{C} \pm 2$ ${ }^{\circ} \mathrm{C}$ and humidity at $\left.65 \% \pm 5 \% \mathrm{RH}\right)$ and has detection range from 10 to $10000 \mathrm{ppm}$ of $\mathrm{CO}[8,9]$.

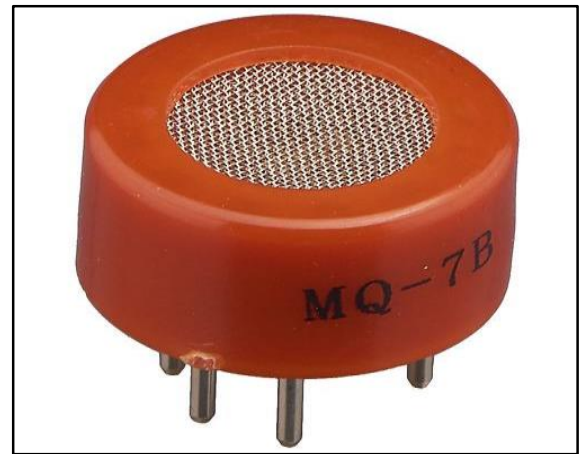

Figure 2 - MQ-7B Carbon Monoxide Sensor (figure source: https://www.terraelectronica.ru/images/icatalog/big/2/2175909-1.jpg)

The next type of carbon monoxide detectors are electrochemical detectors. The work principle of these detectors is chemical production of low power electrical energy by battery cells.

These detectors have very stable and linear dependence characteristic of current from carbon monoxide. The main characteristic of these types of carbon monoxide sensors are high precision in carbon monoxide detection.

The most used sensor elements in electro chemicals carbon monoxide detectors is TGS sensor (Taguchi Gas Sensor). This sensor element was invented in 1968 by Naoyoshi Taguchi, who graduated from Nagata High School in Hyogo Prefecture and enrolled at Osaka Institute of Technology.

He was initiated by newspaper article about a propane explosion at Yamanaka Lake in 1962. Very soon, he understood the need for appropriate gas leak detector and experiments and researchers started [8, $11]$.

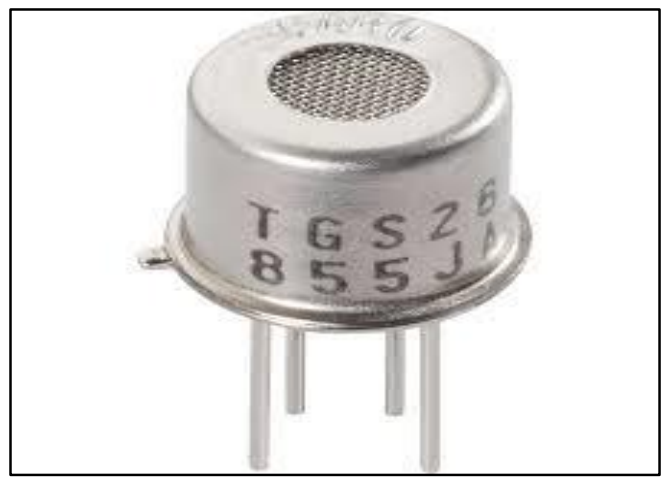

Figure 3 - An example of TGS sensor - TGS-2600 Gas Sensor for air quality various gases (figure source: https://www.conrad-electronic.co.uk/celen/product/183304 /Figaro-183304-TGS2600-Gas-Sensor-For-Air-Quality-Variousgases-air-pollution- $x-H-92-m m-x-78-m m)$

An example of TGS sensor and a view of wireless carbon monoxide detector is presented on figures 3 and 4. 


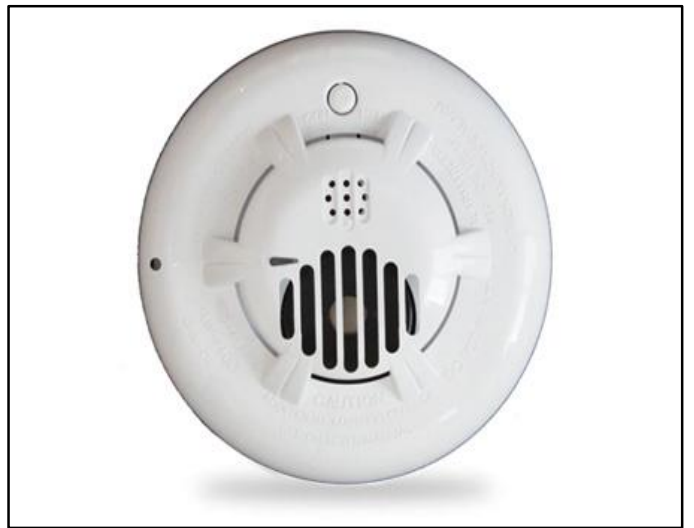

Figure 4 - Wireless Carbon monoxide detector (figure source: https://www.2gig.com/products/sensors/wireless-carbon-monoxide-detector/)

The way of functioning of optical-chemistry detectors of carbon monoxide is to change the colour in the contact with carbon monoxide. They were very cheap with low protection level and for today purposes, they are considered as outmoded.

Bio-imaging sensors detectors have disk made from synthetic haemoglobin which reacts at the same way as haemoglobin in human`s organism.

According to the modern standards, carbon monoxide detectors must satisfy some demands. At the first place, their usage is mandatory in hospitals, schools, hotels and every rooms where people, children, old persons and persons with disabilities resident. Alarm signal, generated according appropriate carbon monoxide presence, must be different than other types of detectors. Also, these detectors must have indications about all potential types of malfunctions and potentials for correct functioning test. Power supply for these detectors must provide correct functioning of these detectors even in the case when central unit for fire detection is out of function $[8,12-14,15]$.

\section{CARBON MONOXIDE DETECTORS INSTALLATION RULES}

Systems for carbon monoxide detection are divided in the two basic groups, irrespective to work principals of their sensors parts.

The first group presents systems with collective address. The main characteristics of these systems are zone distribution with cables structure, star topology with one or more detectors per zone and the information about carbon monoxide concentration at zone level.

The second group of these systems presents analogy addressable systems. The main characteristics of these systems are that every detector presents microprocessor device with simply address and presents component part of address line; the maximal number of addresses connected on one line can be up to 127 and the fact that the information about carbon monoxide is available at the level of individual detector [15].

Installation rules for carbon monoxide detectors are based on several very important facts related to carbon monoxide: the location in some particular object where carbon monoxide can appear, ventilation absence, potentials for fire occurrences with incomplete combustion and molecular mass of carbon monoxide, which influences on installation height. Related to noted facts, it can be concluded that in some cases, detection of carbon monoxide must have advantage related to other kinds of detections while in some cases these type of detectors should not be used.

In the cases where optical smoke detectors can't be applied because of false alarms, in the cases where the stratification effect is possible, in the cases where risk of smouldering fires exists and in the cases where the room 's area is not bigger than $50 \mathrm{~m}^{2}$, carbon monoxide detectors must be used as main detection method. As additional protection, beside smoke detectors, carbon monoxide detectors can be installed in cases when potentials for smouldering fires exit and in the cases when the risk of fire in closed area exists. The installation of carbon monoxide detectors are not recommended in evacuation routes, rooms with overheat potentials, rooms with gasses and miscellaneous fumes and vapours and in cases where is possible fast development of fire [8].

According to the international standard ISO 7240, (Part 6: Carbon-monoxide fire detectors using an electro-chemical cell and Part 8: Carbon-monoxide fire detectors using an electro-chemical cell in combination with a heat sensor) carbon monoxide detector satisfied demands for installation in the case when for any carbon monoxide concentration increasing rate smaller than $1 \mathrm{ppm} /$ minute detector detects alarm condition before reaching of $60 \mathrm{ppm}$. It is interesting that one part of the standard related to electrochemical detectors notes that the minimal value of alarm threshold should be $25 \mathrm{ppm}$ while the maximal value of alarm threshold should not be over $45 \mathrm{ppm}$ [15]. According to standard EN 54-14, precise rules for carbon monoxide detectors installation were not defined. Giving the fact that the specific weight of carbon monoxide is very close to specific weight of air, there were references that the installation height of carbon monoxide detectors should be about $1.5 \mathrm{~m}$, in the breathing level of a human. It is interesting that for any change of carbon monoxide for $1 \mathrm{ppm} / \mathrm{min}$ detector must react before the concentration of carbon monoxide reaches 60 ppm (EN 5426: Point fire detectors using carbon monoxide sensors) [17]. According to standard VDE 0833-2, precise rules for carbon monoxide detectors installation were not defined [18]. 
According to standard BS 5839-6, rules for carbon monoxide detectors are the same as for other smoke detectors with note that electro chemical cell has lifetime of seven years [19].

According to standard НПБ 71-98, the main rule is that carbon monoxide detector must react in range from 20 to $80 \mathrm{ppm}$. Related to that fact, there are two classes of fire detectors: the class that can detect concentrations in range from 20 to $40 \mathrm{ppm}$ and class that can detect concentrations in range from 41 to 80 ppm [20].

According to standard NFPA 72, detail procedures and rules for carbon monoxide detectors can be found in NFPA 720 (Standard for the Installation of Carbon Monoxide (CO) Detection and Warning Equipment). This standard demands the installation of carbon monoxide detectors in rooms with presence of children, old persons, persons with disabilities, hospitals and other similar rooms. The exact location of detectors should be determined related to evaluation of potential carbon monoxide sources also with evaluation of potential false alarms occurrence. The location of ventilation and air-condition systems must be considered. For appliances of carbon monoxide detectors in objects such as public auto garages and similar objects, it can be considered that the cover range of carbon monoxide detectors is the same as cover range of point smoke detectors. That means that the covering radius was from $8 \mathrm{~m}$ to $12 \mathrm{~m}$. The distance from the wall should be at least 12 inches-about $30 \mathrm{~cm}$. The suppliers define covering range of carbon monoxide detector from 5000 foots $^{2}$ to 10000 foots $^{2}$, with the installation height of $5 \mathrm{ft}$. At the other words, the average radius distance is 49 foots (about $15 \mathrm{~m}$ ) [21]. It is also interesting, for United States only, that there were some differences in appliance and usage of carbon monoxide detectors between different states. For example, according to the state statute, 27 states require carbon monoxide detectors in private dwellings; five require carbon monoxide detectors in school buildings; 14 require carbon monoxide detectors in hotels and motels-three of those states have complementary administrative regulations while two of those states have requirements through administrative regulations alone [22].

In the most of European countries standards, the rules for covered area of carbon monoxide detectors are the same as the rules for installation of smoke detectors. It is also important to note that the standard ISO 9705-1:2016(en): Reaction to fire tests -Room corner test for wall and ceiling lining products - Part 1: Test method for a small room configuration should be considered if carbon monoxide products and other toxic products during combustion can be occurred at the early stage of burning. This standard contents test methods for evaluation of walls and ceilings reactions in small rooms exposed to fire.

The most common characteristics of carbon monoxide detectors for the most suppliers are from 30 to $75 \mathrm{ppm}$, in depending of appliance.

It is also important to note that in the lack of ventilation, the part of the carbon monoxide in combustion products can be huge and its concentration is much bigger than the concentration of carbon dioxide while the part of carbon monoxide in the open space is almost negligible. The stratification effect has less influence on carbon monoxide detectors than the other types of detectors [8].

Figures from 5 to 8 present installation of carbon monoxide detectors in different cases.

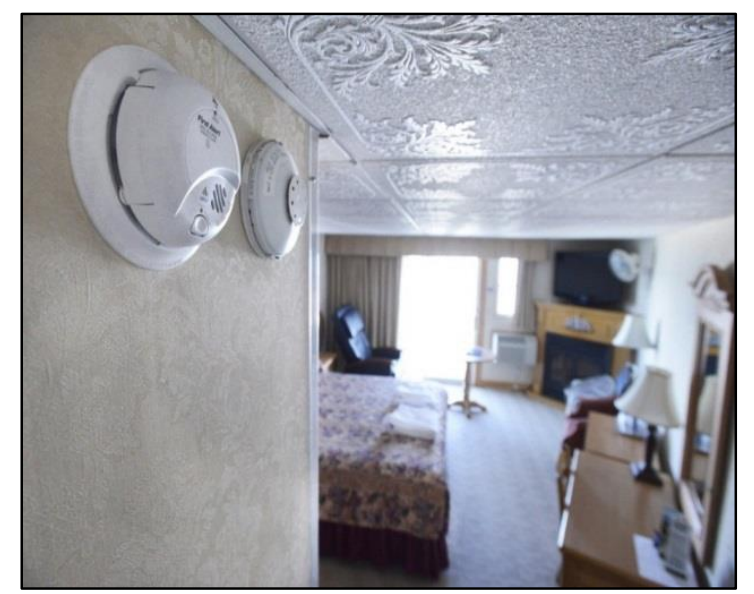

Figure 5 - Installation of carbon monoxide detector (in combination with smoke detector, left) in hotel room (figure source: https://www.pressherald.com/2015/04/06/maine-bill-wouldrequire-carbon-monoxide-detectors-at-moresites/)

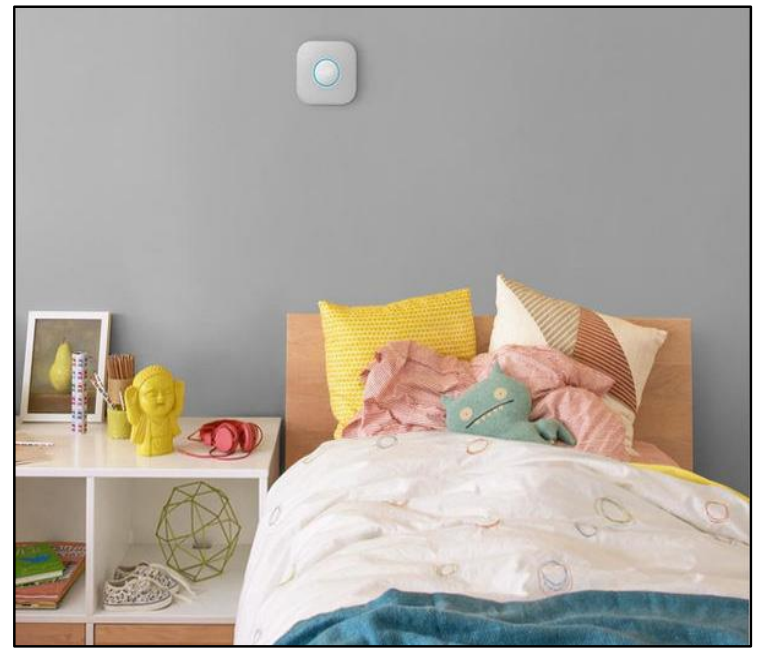

Figure 6 - Installation of carbon monoxide detector in bedroom (figure source: https://brain-imagesssl.cdn.dixons.com/8/5/10133858/l_10133858 _002.jpg) 


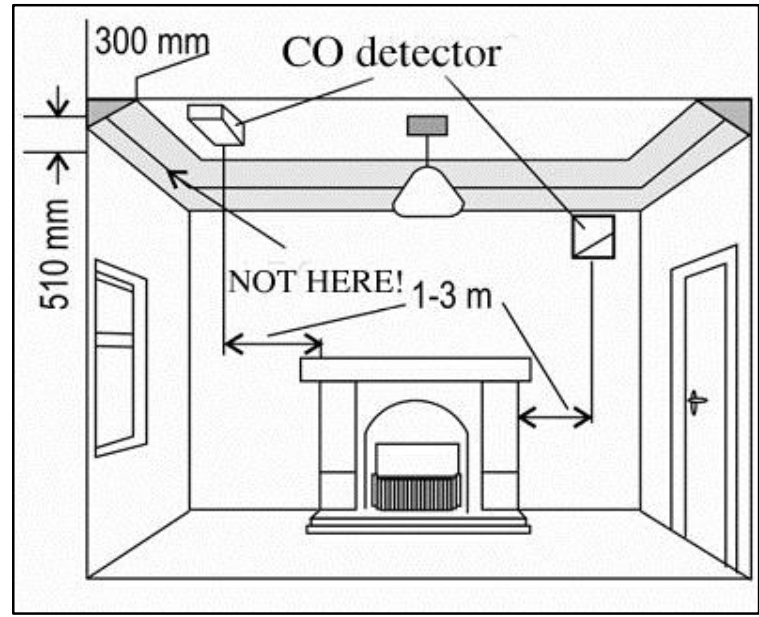

Figure 7 - Installation of carbon monoxide detectors in the room with chimney (figure source: Blagojevic, Đ. M.: Fire protection systems designing, pp. 132)

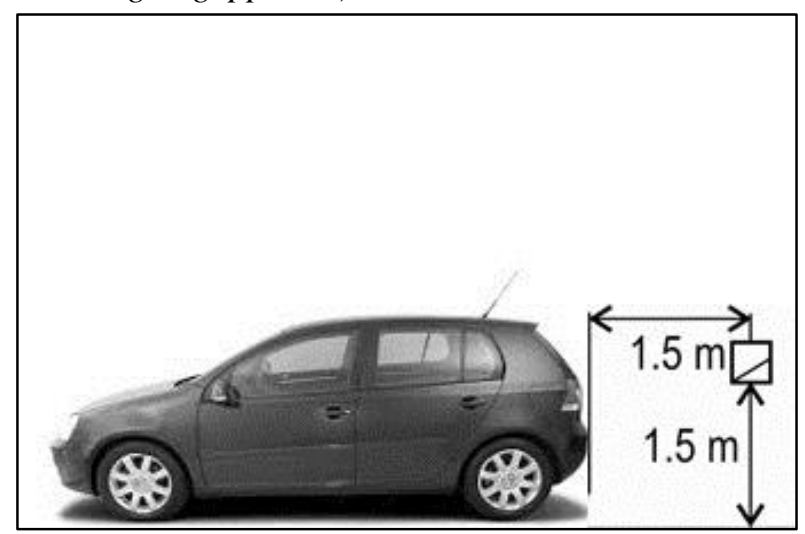

Figure 8 - Installation of carbon monoxide detectors in garages

According to the rules for alarm systems designing in garages, there were two rules that should be noted. IMC-international mechanical code presents that in underground garages ventilation systems are not in obligation to work constantly wherever system was made to activate when the carbon monoxide concentration reaches $25 \mathrm{ppm}$. UMC-uniform mechanical code presents that in all parking garages system for carbon monoxide detection can be set to activate ventilation system in order to maintain maximal average concentration of carbon monoxide of $50 \mathrm{ppm}$ for any moment during eight-hour period or carbon monoxide concentration of $200 \mathrm{ppm}$ in period not longer than one hour [15].

\section{CONCLUSION}

Carbon monoxide presents great danger for human health in the senses of poisoning and explosion. Its occurrence is usually in the closed spaces and areas in the uncompleted combustion conditions, what is very danger and hard for evacuation and saving endangered people and fire fighters. For those reasons, carbon monoxide detection must be extremely precise, correct and professionally realized, carbon monoxide detectors must covered every potential space or area where carbon monoxide could be occur, no matter on cost because even one human life doesn't have price. Of course, continual following of scientific solutions and researches also must be priority in fight against carbon monoxide for safe and more quality human life.

\section{REFERENCES}

[1] Blagojević Đ. M, Alarm systems, Faculty of occupational safety in Niš, ISBN 978-86-6093-025-7, pp. 68, 69 , 75, Niš, 2015.

[2] Jevtić B. R, Selection of the fire detectors and their arrangement in object, Bezbednost, UDK 343+351.74./75(05), YU ISSN 0409-2953, Vol 1/2015, pp. 197-215, Beograd, Srbija, 2015.

[3] Njekrasov V. B, General Chemistry, Third edition, Naučna knjiga, pp. 333, Beograd, 1965.

[4] Group of authors, Chemistry and technology handbook, Publicher working organisation Rad, pp. 923, 924, Belgrade, 1987.

[5] Radošević N, Chemists and technologist handbook, Technical book, pp. 1305, 1311, 1374, Belgrade, 1968.

[6] Aranđelović M, and Jovanović J, Medicine of work, Medicine faculty in Niš, University of Niš, ISBN 8680599-52-2, pp. 125, 126, Niš, 2009.

[7] https://www.detectcarbonmonoxide.com/co-healthrisks/.

[8] Blagojević Đ. M, Fire protection systems designing, AGM Book, Belgrade, ISBN 978-86-86363-89-3, pp. 75, 125-132, Niš, 2018.

[9] https://www.aliexpress.com/item/co-detection-MQ7B-carbon-monoxide-sensor-element-civilianalarm-dedicated/32827613078.html

[10]https://www.figaro.co.jp/en/company/history.html.

[11]Clifford P. and Tuma, D, Characteristics of semiconductor gas sensors I. Steady state gas response, Sensors and authors, Vol. 3, pp. 233-254, 1983.

[12]https://www.ligris.com/2016/12/smoke-and-carbonmonoxide-detector-rules-revised-as-of-december-12016/

[13]https://www.blainemn.gov/DocumentCenter/View/4 67/Smoke-and-Carbon-Monoxide-Alarms-PDF.

[14]http://specinstalacije.etf.rs/predavan/glava_5/ dojavaPozara.pdf 
[15]Jović M, The way or realisation and appliance of carbon monoxide detectors, final paper, Faculty of occupational Safety, University of Niš, pp. 14,15, 18,19, 44, Niš, 2018.

[16]ISO 7240, Fire detection alarm systems, 2003-2014

[17]EN 54, Fire detection and fire alarm systems, 19962015.

[18]DIN VDE 0833-2, Alarm systems for fire, intrusion and hold up, 2009.

[19]BS 5839-6: Fire detection and alarm systems for buildings. Code of practice for the design and installation of fire detection and alarm systems in dwellings, 2004.
[20]НПБ 71-98, Извещзатели пожарные газовые. Общиие технические требования. Методы испьтаний, 1998.

[21]NFPA 720, Standard for the Installation of Carbon Monoxide (CO) Detection and Warning Equipment, 2009.

[22]http://www.ncsl.org/research/environment-andnatural-resources/carbon-monoxide-detectors-statestatutes.aspx

\section{REZIME}

\section{INSTALACIJA DETEKTORA UGLJEN MONOKSIDA}

Jedan od najvažnijih zadataka u zaštiti od požara je raspored detektora požara u objektu. Detektori požara mogu biti podeljeni na različite načine, u zavisnosti od različitih faktora. Njihov izbor, raspored, broj i lokacija zavisi od mnogo različitih faktora. Jedan od najkomplikovanijih i najzahtevnijih detektora požara je detektor ugljen monoksida. Ovaj rad je napisan s ciljem da prikaže raspored detektora ugljen monoksida, njihovu realizaciju i glavna pravila za postavljanje u odnosu na neke validne standarde.

Ključne reči: detektor, raspored, $\mathrm{CO}$, standard 